\title{
On English-Chinese Translation of Public Service Announcements from the Perspective of Skopos Theory
}

\author{
HU Mengting \\ Xi’an Shiyou University, Xi'an, China \\ Received: July 2, 2021 \\ Accepted: November 27, 2021 \\ Published: January 31, 2022
}

To cite this article: HU Mengting. (2021). On English-Chinese Translation of Public Service Announcements from the Perspective of Skopos Theory. Asia-Pacific Journal of Humanities and Social Sciences, 1(4), 126-134, DOI: 10. 53789/j. 1653$\underline{0465.2021 .0104 .016}$

To link to this article: https://doi. org/10.53789/j. 1653-0465.2021.0104.016

\begin{abstract}
Unlike traditional commercials, public service announcements (PSAs) aims to raise awareness of critical social issues and change public attitudes and behavior instead of selling a product or service. Translating English PSA slogans into Chinese can introduce Chinese citizens to the predominant style of PSAs, thus extensively promoting Chinese engagement in global public service announcements, highlighting its social function. At the same time, Vermeer's Skopos theory centers on the function of the target text. Therefore, Skopos's theory can be used to guide PSA translation. This paper explores translation methods of English-Chinese PSA slogans from Skopos theory.
\end{abstract}

Keywords: Skopos theory; PSAs; translation methods

Notes on the contributor: HU Mengting is pursuing her master's degree in English-Chinese translation and interpreting at Xi'an Shiyou University.

\section{Introduction}

Public service announcements (PSAs), also known as public service advertisements or advertising, aim to educate people on social issues related to the public interest and often encourage action or response ${ }^{1}$. PSAs cover environmental protection, physical and mental health, safety, crime, and civil rights. They are an essential part of public social welfare. Therefore, it is essential to research PSAs and PSA translation.

According to previous research, "public service announcement" was coined in the USA during World War II, dramatically developing in the past decades. In this paper, the author will explore the translation methods based on Vermeer's Skopos theory and show four translation methods: literal translation, free translation, idiomatic translation, and addition. 


\section{Vermeer's Skopos Theory}

Skopos theory is a German functionalist theory that concentrates on communication, target-oriented translation, and target readers. Hans Vermeer made a remarkable contribution to functionalist theory by developing Skopos theory in the 1970s, which became the core of the functionalist translation approaches. He believes that each text is produced for a given purpose and should serve this purpose ${ }^{2}$.

Skopos theory covers three rules: the Skopos rule, the coherence rule (intra-textual coherence), and the fidelity rule (inter-textual coherence). First, the Skopos rule is of primary importance. "Skopos" is a Greek word for "purpose, aim or function" ${ }^{3}$. According to the rule, the purpose of a translation justifies the translation process, and the end justifies the means ${ }^{4}$. Therefore, the translation method is determined by the purpose of the communication. Second, the coherence rule, or intra-textual coherence, states that a translation should be understandable and acceptable to the target receivers and make sense in the communicative situation and culture. Third, the fidelity rule requires that the target text be faithful to the source text ${ }^{5}$.

Skopos theory, the fidelity rule is subordinated to the coherence rule, and both the coherence rule and the fidelity rule are subordinated to the Skopos rule. If the Skopos rule requires the target text to differ from the source text, the fidelity rule is not suitable anymore. If the Skopos rule requires the target text to be incoherent, the coherence rule is not valid anymore.

In short, theSkopos rule, namely the purpose or function, is a top priority in the translation process. So is in the translation of public service announcements. The translation of PSA slogans encourages public participation in international initiatives by broadening their global accessibility, highlighting its social function as PSAs are also function-oriented. While Vermeer's Skopos theory also centers on the function of the target text. Therefore, Skopos's theory can be used to guide PSA translation.

\section{English-Chinese Translation Methods of PSA Slogansunder the Guidance of Skopos Theory}

It will be specifically analyzed in this part that how to translate English PSA slogans into Chinese from the perspective of Skopos theory.

\section{1 Literal translation}

The literal translation means transferring "the grammatical structure of source language into the similar structure in the target language, with the vocabulary equivalently translated". ${ }^{6}$

(1) Source text: Only You Can Prevent Forest Fires

Target text: 只有你才能預防森林火災

Created by the Advertising Council (Ad Council), an American non-profit organization that produces and promotes PSAs, Smokey Bear and his powerful warning Only You Can Prevent Forest Fires represent the longest 
-running and one of the most successful PSA campaigns in the United States - the wildfire prevention campaign $^{7}$. It is necessary to translate this slogan into Chinese since wildfires are a severe issue in China.

This English slogan clarifies with simple words that forest fires prevention requires everyone's effort. Moreover, the Chinese translation keeps the same word use and grammatical structure as the source text, conveying the same meaning in the same style. That is to say, this literal translation fulfills the coherence rule and fidelity rule of Skopos theory. Besides, Chinese people can arouse consciousness and prevent wildfires through the effective Chinese translation, which fulfills the Skopos rule. Therefore, this is an excellent example in line with Skopos theory.

(2) Source text: Friends Do Not Let Friends Drive Drunk

Target text: 是朋友就不要讓朋友酒後駕車

This is a slogan of the Drunk Driving Prevention campaign created by the Ad Council and the National Highway Traffic Safety Administration in $1983^{8}$. Drunk driving is also a big problem in China. Translating this slogan into Chinese is of great importance.

The Chinese translation “是朋友就不要讓朋友酒後駕車” expresses the exact meaning of the original slogan Friends Don't Let Friends Drive Drunk, both grammatically and semantically, creating awareness of the dangers of drunk driving for Chinese people. Thereby, the coherence rule, the fidelity rule, and the Skopos rule of Skopos theory are successfully fulfilled at the same time.

(3) Source text: Start Talking Before They Start Drinking

Target text: 在他們飲酒之前就和他們溝通

This is a slogan of underage drinking prevention proposed by Ad Council, which indicates that parents play a crucial role in stopping their children from using alcohol ${ }^{9}$.

The Chinese translation follows the same structure of the source text, both catchy and original. What is more, the Chinese vision “在他們飲酒之前就和他們溝通” prompts Chinese parents to prevent their children from drinking as well. Hence, the Skopos rule, the coherence rule, and the fidelity rule are all fulfilled in this literal translation.

(4) Source text: This Is Your Brain. This Is Your Brain On Drugs.

Target text: 這是你的大腦; 這是你吸毒時的大腦

This Is Your Brain. This Is Your BrainOn Drugs was a large-scale US anti-narcotics campaign by Partnership for a Drug-Free America (PDFA) launched in 1987. Using a fried egg as a symbol of a human's brain on drugs, this famous TV ad significantly contributed to the American anti-drug campaign ${ }^{10}$. An anti-drug campaign is a worldwide campaign shared by nations. Therefore, it is of great necessity and importance for Chinese people to know it.

Following the coherence rule and the fidelity rule of Skopos theory, the Chinese translation “這是你的大 腦; 這是你吸毒時的大腦” conveys the message of preventing drug use in Chinese by way of remaining the same word and grammar as the English slogan. What is more, the translation effectively arouses the awareness of the anti-drug campaign for the Chinese, which fulfills the Skopos rule.

(5) Source text: A Drug-Free World - We Can Do It. 


\section{Target text: 無毒世界一我們能做到}

International Day against Drug Abuse and Illicit Trafficking is an international day supported by the United Nations International Drug Control Program to fight against substance abuse and the illegal trade of drugs, annually observed on June 26th worldwide ${ }^{11}$.

The slogan above was the theme for this campaign in $1998^{12}$. The source text uses some simple words and clarifies that the whole world should fight against drug abuse. Meanwhile, the target text keeps the same word use and grammatical structure as the source text in the Chinese translation. Furthermore, it equals the original slogan both in meaning and style. That is to say, this literal translation fulfills the coherence rule and fidelity rule. Finally, Chinese people can arouse consciousness and fight against drug abuse through the Chinese translation, which fulfills the Skopos rule. Therefore, this is an excellent example in line with Skopos theory.

\section{A. Free Translation}

Free translation refers to reproducing the general meaning and intention of the original but not strictly following the grammar, style, or organization. Free translation is also commonly used for PSA translation in that the target audience and target culture are the critical points in the PSA translation process ${ }^{13}$. Some examples are as follows.

(6) Source text: It Takes a World to End Violence against Children

Target text: 童享零家暴, 世界更美好

World Vision International is the largest child-focused private charity in the world. It is a Christian humanitarian and service organization dedicated to meeting the emergency needs of missionaries ${ }^{14}$.

Violence is the worst crime against children all around the globe. Physical, emotional, and sexual abuse rob children of their future, dignity, and human rights. World Vision International launched a global campaign, It Takes a World to End Violence against Children, in 2017 to advocate for an end of all forms of child abuse ${ }^{15}$. Child abuse also takes place in China. Therefore, translating this message will help bring attention in China to this global crisis. However, if we do the literal translation, the target text would be “結束對兒童的暴力需要一 個世界”, which fulfills the coherence rule and fidelity rule, but not the Skopos rule of Skopos theory. This literal translation is faithful to the original text, and Chinese people can understand the meaning of the slogan. However, this translation does not look and sound very vivid and attractive to Chinese people, so the social function cannot be achieved. Therefore, we choose free translation instead. The free translation method makes the Chinese version “童享零家暴, 世界更美好” more idiomatic, and it is easier for Chinese people to keep in mind and take action to stop child abuse. So this free translation is better than the literal translation because it fulfills the Skopos rule.

(7) Source text: You Can Learn a Lot From a Dummy. Buckle Your Safety Belt.

Target text: 系好安全带, 生命無意外.

Created in 1985, You Can Learn a Lot From d Dummy is a famous PSA slogan to change public attitudes towards safety belt use in the United States ${ }^{16}$. This ad used a dummy as a driver to show what happened when the dummy was driving a car without buckling the safety belt to warn the public of the importance of safety belt use. That is why the slogan says, You Can Learn a Lot From a Dummy. However, when translating it to Chinese, 
the literal version “你可以從假人身上學到很多” does not make much sense without the context. Therefore, we have to go with the free translation. Pointing out a safety belt during driving in the Chinese version is crucially important. Besides, making it in Chinese idiomatic form would be more vivid for Chinese people to keep in mind. That is why “系好安全带, 生命無意外” is a good translation fulfilling the Skopos rule, the coherence rule, and the fidelity rule of Skopos theory.

(8) Source text: Give Something That Means Something

Target text: 小給予大不同

This is a slogan of the Holiday Giving Campaign of the American Red Cross, a non-profit organization that provides humanitarian aid in the United States ${ }^{17}$. The campaign Give Something That Means Something was launched to encourage the public to help those who had lost everything in a disaster or a hospital patient who needs blood ${ }^{18}$. When translating the original slogan into Chinese, the literal translation would be “給予一些有意 義的東西”, which generally conveys the meaning of the original slogan and makes sense to Chinese receivers. The fidelity rule and the coherence rule of Skopos theory are fulfilled. However, Chinese people can barely get the point of the sentence's implications. That is to say, the purpose or the function of this slogan is not conveyed efficiently. Hence, a free translation should be considered. Through the free translation version “小給予大不 同”, Chinese receivers can get the point that we can make a difference for the whole world when we offer our help to others. In this way, the Skopos rule has been satisfied.

(9) Source text: A Mind Is a Terrible Thing to Waste

Target text: 天才可貴, 豈容浪費

A Mind Is a Terrible Thing to the Waste campaign has been enormously successful for four decades since 1972, has helped raise millions for the United Negro College Fund (UNCF) to make college scholarships more accessible to African Americans ${ }^{19}$. The literal translation for this slogan should be “浪費㮩明人是件可怕的事 情”, which makes excellent sense to Chinese people. However, we can make it catchy by following the Chinese idiomatic form. “天才可貴, 豈容浪費” makes a perfect Chinese version of this English PSA slogan with all of the three rules of Skopos theory fulfilled successfully at the same time.

(10) Source text: Tobacco: Deadly in Any Form or Disguise

Target text: 煙草吞噬生命

This is the slogan of World No Tobacco Day in $2006^{20}$. When translating the original slogan into Chinese, a literal translation is not a good option in this case. In the literal translation “任何形式或偽装的煙草都是致命 的”, the word “偽装” does not make much sense according to Chinese grammar and way of expression. In other words, although it fulfills the fidelity rule, it is not suitable for the coherence rule, let alone the Skopos rule. Therefore, free translation may be a better choice for this PSA translation. The free translation version “煙草吞 噬生命” does not follow the fidelity rule, but it fulfills the Skopos rule. The original grammar and word expression were abandoned. However, it is easier for Chinese people to get the slogan's point and arouse awareness on the harmful and deadly effects of tobacco use and reduce tobacco use and second-hand smoke exposure, which fulfills the Skopos rule. As the Skopos theory says, the purpose of the target-oriented translation takes the most important place. 


\section{B. Idiomatic Translation}

Idiomatic translation reproduces the "message" of the original ... by preferring colloquialisms and idioms where these do not exist in the original ${ }^{21}$. It refers to borrowing or imitating the idiomatic expressions from the target language to help target receivers understand and accept the original meaning of the PSA slogan. That is to say, the translator should transform the source text by using idiomatic expressions that are more familiar and acceptable to the target receivers. As PSAs are target-oriented, the translation of PSAs should pay much attention to the purpose and the function of the target text. There are some examples below.

(11) Source text: Wanted! Seas and Oceans - Dead or Alive?

Target text: 海洋存亡, 匹夫有責

This is the theme of World Environment Day in 2004, focusing on protecting seas and oceans ${ }^{22}$. The original text “Wanted! Seas and Oceans - Dead or Alive?” would be translated into “緊急! 海洋——死的還是活 的?" in the way of word-by-word translation. Although it follows the fidelity rule of Skopos theory, it does not make sense to Chinese receivers. In other words, it broke the coherence rule and Skopos rule. Therefore, we need to find another way to translate it and make the target text understandable and acceptable to Chinese people. There is a very famous poem “天下興亡, 匹夫有責” written by Gu Yanwu in the Ming Dynasty, which conveys the meaning that everyone should feel responsible for the fate of the country. When translating the original PSA slogan into Chinese, we can imitate this famous Chinese poem and translate it into “海洋存亡，匹夫有責”, meaning that everyone should feel responsible for the protection of the seas and oceans. This imitation translation allows Chinese receivers to understand the slogan. It arouses Chinese people's consciousness of protecting seas and oceans, which fulfills both the coherence and Skopos. According to Skopos theory, we have to follow the Skopos rule to achieve the purpose and function of the target text but give up faithfulness to the source text.

(12) Source Text: Beat Plastic Pollution

Target text: 塑戰速決

The theme of World Environment Day 2018 was plastic pollution ${ }^{23}$. This planet is drowning in plastic pollution, and every single inhabitant should take action against plastic waste for our shared homeland. China should also make some contribution to this campaign. The original PSA slogan would be translated into Chinese as "打 擊塑膠污染” according to a word-by-word translation, which is not only faithful to the original text but also acceptable to Chinese receivers. However, the social function of the original PSA is not conveyed as much as it could be. Since there is a Chinese idiom “速戰速決”, meaning to solve the problems as quickly as possible, in this point, its meaning is in line with the purpose of the PSA slogan. Besides, the Chinese character "塑” referring to "plastic" sounds the same as the character “速” in the idiom “速戰速決”. Therefore, a perfect translation would be “塑戰速決” by way of imitation, suggesting that plastic pollution is a pressing problem. As a result, the Skopos rule has been successfully fulfilled since the social function of the PSA slogan was performed.

(13) Source text: Should Disaster Strike; Be Prepared

Target text: 居安思危, 有備無患——防備意外

World Health Day, observed on April 7th each year, is sponsored by the World Health Organization (WHO) to arouse global health awareness. Themes throughout the years have varied but always cover current 
world health issues ${ }^{24}$. The PSA slogan above is the theme of $1991^{25}$. The word-by-word translation would be “應該災難襲擊; 做好準備” which makes no sense in Chinese. We can see that the word "should” means “might” in this context. Moreover, the word order should be changed. Hence, the revised version “災難可能襲 來; 做好準備” conveys the meaning of the original text and makes Chinese receivers understand, following both the fidelity rule and coherence rule of Skopos theory.

Nevertheless, it is not catchy enough. There is a well-known Chinese proverb, “居安思危, 有備無患”, which means that if someone is prepared for danger in times of peace, he or she will be safe. This proverb happens to convey a similar meaning as the original slogan. Thus, the proverb can be used as the idiomatic translation of the source text. It may encourage Chinese people to take extra steps to care for health, fulfilling the Skopos rule perfectly.

\section{Addition}

It adds background or cultural information not mentioned directly in the source texts to the target texts for further explanation or supplement to avoid confusion.

(14) Source text: Nature for Water

Target text: 借自然之力, 護綠水青山

World Water Day is annually observed on March 22nd around the globe to advocate for the sustainable management of freshwater resources. The theme of 2018 is "Nature for Water" - exploring nature-based solutions to the water challenges we face in the 21 st century $^{26}$.

If this PSA slogan was literally translated into Chinese word by word, that would be “水的性質” which makes no sense to Chinese receivers. According to the purpose of this campaign, we know the implication behind the slogan is to explore nature-based solutions to the water challenges. Thereby, a meaningful translation of this PSA slogan would be “借自然之力, 護綠水青山” (protect water with the help of nature), allowing the target audience to get the point of the campaign and take action to protect and sustainably manage nature and secure water resources. The function of the target text is performed, and the Skopos rule of Skopos theory is satisfied.

(15) Source text: Getting to Zero

Target text: 行動起來, 向“零”艾滋邁進

Designated on December 1st by the World Health Organization and supported by the United Nations since 1988, World AIDS Day is an international day created to raise awareness for HIV and the resulting AIDS epidemic and to commemorate those who have died of AIDS-related illnesses, often with education on AIDS prevention and control ${ }^{27}$.

The theme for the observance in 2011 was "Getting to Zero" 28 . Based on the literal meaning of this PSA slogan, we can translate it into Chinese as “進入零”, which makes no sense at all to Chinese receivers. In other words, it does not convey enough information about this slogan for the Chinese to understand the context. Hence, it breaks the coherence rule of Skopos theory and is not a good translation. Since the topic is all about AIDS, adding “艾滋” (the Chinese word for AIDS) into the Chinese translation is necessary.

The purpose or function of this PSA slogan is toraise global awareness of HIV and educate people to prevent AIDS. The Chinese translation conveys the same meaning and performs the same function according to the Sko- 
pos rule of Skopos theory. Then a good translation would be “行動起來, 向“零”艾滋邁進” (let us work together to reduce the number of AIDS cases to zero). Although it is not faithful to the original text and breaks the fidelity rule, it fulfilled the PSA slogan's social function and purpose, making it a meaningful translation.

\section{Conclusion}

The PSA slogans play critical roles in raising global awareness of environmental protection, humanitarian aid, and health and safety, among other things. If successful enough, they encourage people around the globe to take action and take care of the planet all human beings share, come to the aid of people all over the world who need help, and pay extra attention to one's own health and safety. The 15 examples above show four translation methods used in the English-Chinese translation of PSA slogans under the guidance of Skopos theory: literal translation, free translation, idiomatic translation, and addition. Since PSA translation is target-oriented and focuses on the purpose and function of the target text, Vermeer's Skopos theory is an excellent guideline to follow in doing English-Chinese translation of PSA slogans.

\section{References}

1 Public service announcement. https://en. wikipedia. org/wiki/Public_service_announcement.

2 LIU Xiaofang. (2014). An analysis on the English translation of public service advertisement of China daily from the perspective of Skopos theory. Master thesis of the Hunan University of Technology.

3 LI Zhen. (2008). Research on translation of public service advertising language. Master thesis of Shanghai International Studies University.

4 Nord Christine. (2001). Translating as a purposeful activity: functionalist approaches explained. Shanghai: Shanghai Foreign Language Education Press.

5 ZHANG Chenxiang. (2007). Functional-purpose theory and applied translation studies. Changsha: Hunan Normal University Press.

6 CHEN Dehong, ZHANG Nanfeng. (2000). Selected western translation theory. Hong Kong: City University of Hong Kong Press.

7 The ad council: https://www. adcouncil. org/campaign/wildfire-prevention.

8 see Falynne Knight, Friends do not let friends drive drunk, . https://swhelper. org/2016/10/11/friends-dont-let-friends-drive -drunk/.

9 Start talking before they start drinking - a family guide. Ad Council. https://www. stopalcoholabuse. gov/media/Underage_ Brochure_508final. pdf.

10 This is your brain on drugs. https://en. wikipedia. org/wiki/This_Is_Your_Brain_on_Drugs.

11 International Day Against Drug Abuse and Illicit Trafficking. https://en. wikipedia. org/wiki/International_Day_against_Drug_ Abuse_and_Illicit_Trafficking.

12 A drug-free world: we can do it: https://digitallibrary. un. org/record/258955? ln =en.

13 FANG Weiwen(2008). Application of Skopos theory in advertisement translation. Journal of Hunan Medical University (Social Science Edition), 10(3), 2.

14 World vision International: https://en. wikipedia. org/wiki/World_Vision_International. 
15 It takes a world to end violence against children: https://www. wvi. org/ittakesaworld.

16 Seat belt education (1985 - Present). https://aef. com/classroom-resources/social-responsibility/ad-council-campaignsmade-difference/seat-belt-education/ .

17 American Red Cross: https://en. wikipedia. org/wiki/American_Red_Cross.

18 Give something that means something: https://www. redcross. org/local/dc-va-md-de/about-us/news-and-events/pressreleases/give-something-that-means-something-. html.

19 New Ads still warn a mind is a terrible thing to waste: https://www. npr. org/sections/codeswitch/2013/06/14/191796469/a -mind-is-a-terrible-thing-to.

20 Tobacco: deadly in any form or disguise: https://pubmed. ncbi. nlm. nih. gov/16731252/.

21 Newmark, P. A. Textbook of translation. London: Prentice Hall International, 1988.

22 World Environment Day 2004: http://www. runiceurope. org/englishevents/environmentday2004. html.

23 World Environment Day 2018: a call to "Beat plastic pollution": http://www. emro. who. int/media/news/world-environment-day-2018-a-call-to-beat-plastic-pollution. html.

24 World Health Day: https://en. wikipedia. org/wiki/World_Health_Day.

25 Should disaster strike: be prepared, World Health Day 1991 / Hiroshi Nakajima: https://apps. who. int/iris/handle/10665/ 45961.

26 World Water Day 2018 - Nature for Water: https://www. unwater. org/world-water-day-2018.

27 World AIDS Day: https://en. wikipedia. org/wiki/World_AIDS_Day.

28 Getting to zero selected as World AIDS Day theme: https://www. unaids. org/en/resources/presscentre/featurestories/2011/ november/20111101 wadtheme.

29 SHAN Xinrong \& JIA Shaodong. (2021). Translation in English and Chinese idioms from metonymy. Asia-Pacific Journal of Humanities and Social Sciences, 1(2), 83-89.

30 CHEN Dongyan \& TANG Guoping. (2021). The C-E translation of Guangxi ethnomedicine works from the perspective of eco -translatology: take the selected edition of Zhuang medicine as an example. Asia-Pacific Journal of Humanities and Social Sciences, 1(3), 190-195.

(Editor: Zoey) 